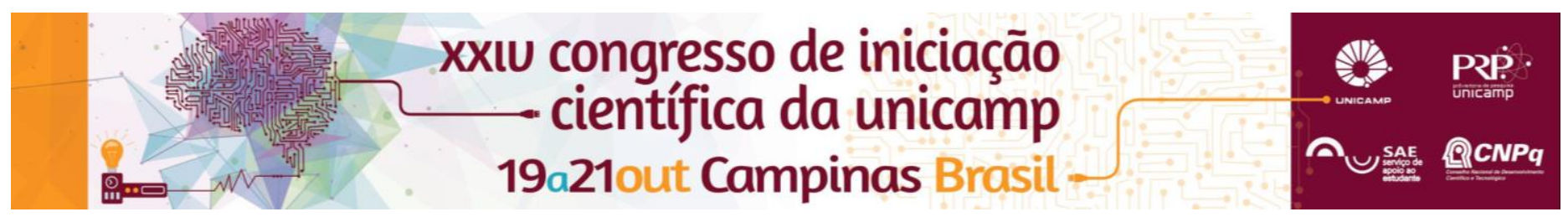

\title{
Influência de diferentes substratos na eficiência de vermifiltração e na dinâmica populacional de minhocas no tratamento de esgoto sanitário
}

\author{
Jonas Henrique R. de Oliveira*(IC), Adzânia Fernandes Leopoldino (IC), Jerusa Schneider (PQ).
}

\section{Resumo}

O experimento tem como objetivo avaliar o desempenho do sistema de vermifiltros - em escala de bancada; colonizados na camada do solo com minhocas; e analisar a influência de diferentes substratos. Observou-se que as minhocas encontraram maior mobilidade em substratos com maiores partículas, de modo a aumentar a eficiência da vermifiltração e que a presença de material vegetal favoreceu a dinâmica populacional de minhocas.

\section{Palavras-chave:}

Tratamento descentralizado, esgoto sanitário, vermifiltração.

\section{Introdução}

O uso de vermifiltro no tratamento de efluente consiste em uma alternativa eficiente e de baixo custo, aos sistemas convencionais. Trata-se de uma solução inovadora que utiliza um filtro biológico de fluxo intermitente que combina o processo vermicompostagem responsáveis pela degradação da matéria orgânica presente no esgoto (Madrid, 2016). Dessa maneira, o objetivo deste trabalho foi avaliar a influência de diferentes substratos (Solo, Areia, Material Vegetal) na eficiência do processo de vermifiltração e na dinâmica populacional de minhocas.

\section{Resultados e Discussão}

Para isso foram confeccionados vermifiltros com garrafasde material PET $(1,5 \mathrm{~L})$ e dispostos na bancada com diferentes substratos, contendo: $S=$ somente solo; $\mathrm{SA}=$ Solo + Areia; $\mathrm{AB}=$ Areia + Braquiária (Figura 1). Em cada vermifiltro foram adicionadas 10 minhocas $(\mathrm{c} / \mathrm{m})$ da espécie Eisenia andrei conduzido com um controle em paralelo, com as mesmas camadas, mas sem minhocas $(\mathrm{s} / \mathrm{m})$, totalizando 6 tratamentos com três repetições.

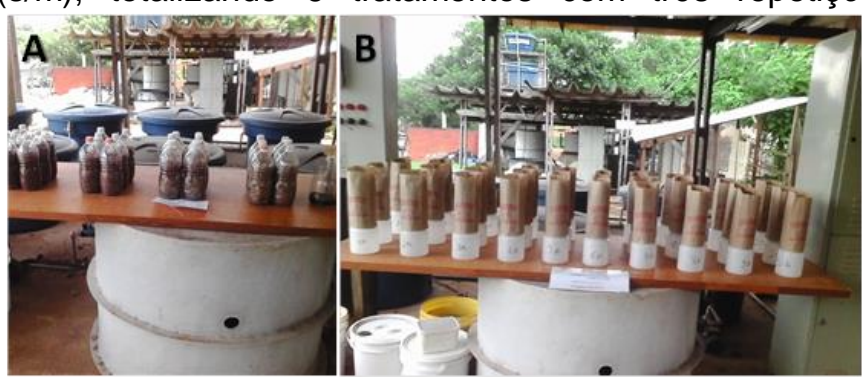

Figura 1. A) Vermifiltros construídos em garrafas pet e dispostos na bancada com diferentes substratos; B) Vermiltros com recipientes plásticos para a coleta do drenado.

Nos vermifiltros foram realizadas aplicações diárias de esgoto bruto coletado por meio de um sistema piloto dentro das dependências do Laboratório de Protótipos Aplicados ao Tratamento de Águas e Efluentes (LabPro) da Faculdade de Engenharia Civil, Arquitetura e Urbanismo (FEC) da UNICAMP. A partir das aplicações de esgoto bruto foi coletado diariamente o líquido drenado (efluente) e feito o registro do volume drenado nos vermifiltros com diferentes substratos.

Observa-se que o substrato é determinante na eficiência da vermifiltração do sistema. Em substratos com a DOI: 10.19146/pibic-2016-52167 presença de areia, observa-se que a presença de minhocas promoveu aumento no volume de efluente drenado; enquanto que quando só tinha solo o volume drenado foi menor (Figura 2).

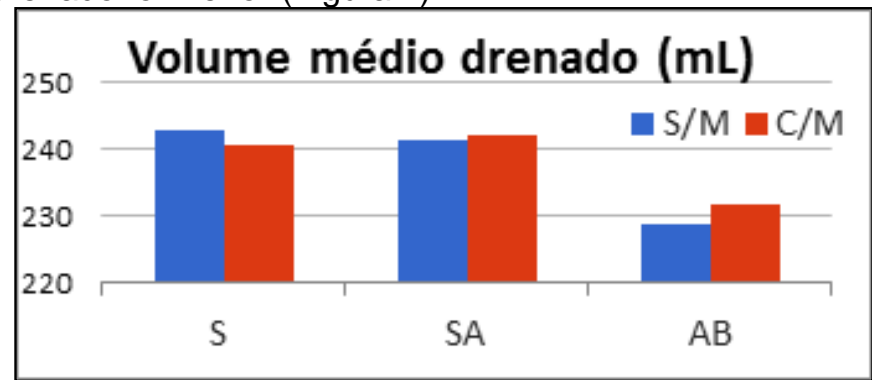

Figura 2. Volume médio drenado nos vermifiltros com diferentes tipos de substratos.

Nota-se que a camada de solo presente nos ensaios nos quais consta somente Solo ou Solo + areia, houve um decréscimo no número de minhocas comparado ao inicio do experimento. Em contrapartida, nos vermifiltros com o substrato Areia + Braquiária, a população de minhocas teve um aumentou 15 vezes (Tabela 1).

Tabela 1.Número total e peso de minhocas nos vermifiltros com diferentes substratos após 68 dias.

\begin{tabular}{ccc}
\hline Substratos & Número total & Massa total (g) \\
\hline S & 4 & 0,67 \\
SA & 5 & 0,67 \\
AB & 155 & 3,67
\end{tabular}

\section{Conclusões}

As minhocas encontram maior mobilidade em substratos com partículas maiores, de modo a criar novos caminhos e facilitar a filtração, em contrapartida ao que se observou em substratos mais compactos. Além disso, apresentam maior capacidade de se adaptar a substratos que contem com a presença de material vegetal, favorecendo a dinâmica populacional de minhocas do sistema.

\section{Agradecimentos}

A minha família, acima de tudo; à Professora Jerusa, pelo voto de confiança; à Adzânia pelo apoio e amizade; e Danielle Sleiman, Gabriele Foschini, Pâmela Kinjô e Stephanie Naomi pelo apoio.

Madrid, F. J. P. L. Aplicação da vermifiltração no tratamento de esgoto sanitário. 2016. Disertação (Mestrado em Engenharia Civil) -Faculdade de Engenharia Civil Arquitetura e Urbanismo, Universidade Estadual de Campinas. 